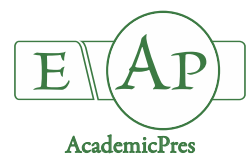

\title{
Determination of Blooming, Pollen and Fruit Set Characteristics in Punica granatum
}

\author{
Deniz AKSOY ${ }^{1}$, Zeynel DALKILIÇ ${ }^{2 *}$ \\ ${ }^{1}$ Aegean Agricultural Research Institute, Cumburiyet Mah. Çanakkale Asfaltı Cad., No 57, 35660 Menemen, İzmir, \\ Turkey;denizaksoy75@gmail.com \\ ${ }^{2}$ Aydin Adnan Menderes University, Faculty of Agriculture, Department of Horticulture, South Campus 09100 Aydin, \\ Turkey; zdalkilic@adu.edu.tr (*correspondingauthor)
}

\begin{abstract}
The objective of this study was to investigate flowering, pollen, and fruit set characteristics of locally registered pomegranate cultivars between two consecutive years. 'Dr. Ercan 35', 'Efenar 35', 'Kamilbey 35', and 'Tezeren 35' cultivars have been developed by cross-breeding programs. Open-, cross-, and self-pollination studies were performed with these cultivars using three trees in each replicate in the field. Number of anthers per flower, number of pollen grains per anther, viability, and germination tests were conducted in the laboratory. Fruit set ratio of self-pollinated combinations were lower than open-pollination. The fruit set ratio from self-pollination was obtained from 'Dr. Ercan' (60.3\%), 'Efenar 35' (62.4\%), 'Kamilbey 35' (50.5\%), and 'Tezeren 35' (25.2\%). The highest fruit set ratio (49.7\%) was obtained from 'Kamilbey 35' × 'Dr. Ercan 35' combination. The highest number of characteristics was as follows: 'Tezeren 35' (402 anthers/hermaphrodite flowers), 'Kamilbey 35' (8550 pollen/anther, male flowers in the beginning of flowering), 'Efenar 35' (84.7\% pollen viability, hermaphrodite flowers), 'Kamilbey 35 ' (71.2\%, pollen germination, hermaphrodite flowers). In conclusion, at least one, two or more, pollinator cultivars are necessary for commercial plantations using with these recently released pomegranate cultivars.
\end{abstract}

Keywords: breeding; pollination; pollen number; pomegranate; viability and germination ratio

\section{Introduction}

Pomegranate (Lythraceae, syn. Punicaceae, $2 n=2 x=16$ ), is one of the vitamin, nutrition, and antioxidant sources in human health (Mars, 1998; Jalikop, 2010; Gözlekçi et al., 2011; Melgarejo et al., 2012). Pomegranate has been known as one of the first cultivated plants around Fertile Crescent dated back to 11 million years ago in fossil records (Gözlekçi, 2014). As a temperate-zone fruit crop, it was believed that pomegranate was domesticated around 3,0004,000 B.C. in north Iran, southeast Turkey, Caucasus, and India, among figs, dates, olives, and grapes (Onur, 1988; Stover and Mercure, 2007). Turkey was in the fourth place with $445,750 \mathrm{t}$ in pomegranate production while China $(1,200,000 \mathrm{t})$, Iran $(1,009,890 \mathrm{t})$, and India $(743,000 \mathrm{t})$ were other leading countries (Anonymous, 2017). Turkey exported 137,000 $\mathrm{t}$ pomegranate fruit in 2013. Besides fresh consumption, pomegranate fruit can be used for juice, patisserie, spice, pharmaceutical, staining, oil, animal feed, tannen, pectin, and vinegar industry (Onur, 1988; Y1lmaz, 2007; Yazıc1 and Sahin, 2016).

Pomegranate has andromonoecious type flowers, which means both hermaphrodite and functionally male flowers occur on the same tree (Holland et al., 2009; Wetzstein $e t$ al. 2011). While hermaphrodite flowers set fruit, male flowers serves as pollen source for adequate pollination.

The number of male flowers is 1.5-4.5 times more than hermaphrodite flowers (El-Kassas et al., 1998; Engin and Hepaksoy, 2003). In contrast, the pollen viability of hermaphrodite flowers is lower than that of male flowers (Gözlekçi and Kaynak, 2000). For these reasons, the quantity and quality of male flowers are important for sufficient pollination and fruit set in modern pomegranate orchards. During a relatively long flowering season, from April to July, there are more hermaphrodite flowers than male flowers in the beginning of the flowering (Onur, 1988; Tibet and Baktır, 1991). In general, the fruit set was found 3-9\% (Onur, 1988). The fruit set was observed as 5.9-10.6\% in 'Canernar' and 5.7-12.1\% in 'Hicrannar' (Dalka, 2010). Insects, especially honeybees, play an important role in pollination (Derin and Eti, 2001).

The objective of this study was to investigate flowering, pollen number, viability and germination, and fruit set characteristics of some registered 'Dr. Ercan 35', 'Efenar 35', 'Kamilbey 35', and 'Tezeren 35 ' pomegranate cultivars. The pollination biology of these pomegranate cultivars was determined at the first time with this research. 


\section{Materials and Methods}

\section{Biologicalmaterial}

'Dr. Ercan 35' ('İzmir 1513’ × 'İzmir 1445’), 'Efenar 35’ ('İzmir 1445' x 'İzmir 23'), 'Kamilbey 35' ('İzmir 23’ × 'İzmir 1445') and 'Tezeren 35' ('İzmir 1513' x 'İzmir 23') pomegranate (Punica granatum L.) cultivars (registered in 2015) located at Aegean Agricultural Research Institute (ETAE), Menemen, İzmir, Turkey were used as plant material in the experiments conducted in 2016. 'Efenar 35' and 'Kamilbey 35' cultivars were previously obtained from the reciprocal cross of the same parents. The experimental plants were 8 years old and planted $4.0 \times 2.5 \mathrm{~m}$ distance between and within rows. In each treatment, there were three replicate trees were used.

Phenological observations

The beginning of flowering, full flowering and end of flowering dates was recorded in both hermaphrodite and male flowers.

\section{Self-pollination, cross-and open-pollination}

The self-pollination experiments were conducted under $3.2 \times 3.0 \times 3.3 \mathrm{~m}$ dimension cabinets made by white nylon mash to prevent insect entry from outside (Küçük, 2003). In each cabin, one bombus (Bombus fervidus) beehive was replaced. For the controlled cross-pollination (hybridization) experiments, the flowers were emasculated by hand, removing sepals, petal and stamen with sharp razor blade without disturbing the pistil at balloon stage. Three branches approximately $1.5-2.0 \mathrm{~m}$ above the ground were chosen from four directions of the plants. The flowers from each cultivar were collected at balloon stage and brought to the laboratory. The anther and pollen preparation was performed according to Engin and Hepaksoy (2003) and Üstüntaş et al. (2019). Pollen of each cultivar was used as a male parent for other three cultivars (full-sib design). Openpollination experiments were conducted by choosing and labeling three branches in each tree. The fruit set of hermaphrodite type of flowers were counted at harvest.

Anther numbers, pollen number, viability, and germination rate of pomegranate cultivars

Both hermaphrodite and male flowers were collected at the balloon stage at three different times namely, the beginning, full, and end of flowering. Anthers were counted as three replicates from ten flowers. The anthers were burst overnight spreading onto a white paper under a lamp at 25 ${ }^{\circ} \mathrm{C}$ in the laboratory. Pollen grains were stored in a small glass vials in the refrigerator until they are used for pollination. The pollen number, viability and germination tests were performed according to Eti (1991).

The number of pollen grains was calculated using hemocytometer modified from Eti (1990). The viability test of pollen grains was performed by TTC $(2,3,5$ triphenyl tetrazolium chloride) according to Eti (1991). The redcolored pollen grains were recorded as viable after $2 \mathrm{~h}$ incubation observed at $10 \times 10$ magnification.

Pollen grain germination test was performed with agar + sucrose method using $15 \%$ sucrose, $25 \mathrm{ppm}$ boric acid with 1\% agar according to Engin and Hepaksoy (2003). The germination was recorded $24 \mathrm{~h}$ after pollen plating. The germination ratios were determined by dividing the number of pollens germinated by the total number pollens in the field of light microscope view according to Günver-Dalkılıç and Dayi-Doğru (2003). Data were analysed as completely randomized design with three replicates. Differences between means were determined by LSD test at $\mathrm{p}<0.05$ level.

\section{Results and Discussion}

\section{Phenological observations}

Although bud swelling times were very close in all cultivars, bud burst times were different in the field (Table 1). The bud burst in 'Dr. Ercan 35' and 'Efenar 35' were observed one week before 'Kamilbey 35' and 'Tezeren 35' cultivars. While hermaphrodite flowers in 'Efenar 35' and 'Kamilbey 35' opened earlier than male flowers, that of in 'Dr. Ercan 35' and 'Tezeren 35' opened later than male flowers. Corresponding flowering period for cultivars lasted approximately one month allowing for cross-pollination to each other.

\section{Self-, cross-and open-pollination}

The fruit set ratios from different pollination experiments were changed between $9 \%$ and $85 \%$ (Table 2). The highest fruit set was obtained from open pollination from $60.1 \%$ in 'Tezeren 35 ' to $85.0 \%$ in 'Dr. Ercan 35'. In self-pollination, the fruit set ratios were changed from $25.2 \%$ in 'Tezeren 35 ' and 62.4\% in 'Efenar 35'. While the highest fruit set ratio was obtained as $49.7 \%$ in 'Kamilbey 35 ' $x$ 'Dr. Ercan 35' combination, the lowest of that was obtained as 9\% in 'Efenar 35' x 'Dr. Ercan 35' combination (Table 2). This means that more than one cultivar existence in the pomegranate orchard should be preferred (Derin and Eti, 2001).

In open pollination, the fruit set ratio was between $4.1 \%$ in 'İzmir 1445' and 94.2\% in 'İzmir 1513' cultivars (Küçük, 2003). The fruit set ratios were obtained as $56.3 \%$ in 'Hicaz' open pollination, $61.1 \%$ in 'Hicaz' $\times$ 'Hicaz' (male flower) selfing, $57.6 \%$ in 'Hicaz' $\times$ 'Hicaz' (hermaphrodite flower) selfing, $78.9 \%$ in 'Hicaz' $\times 33 \mathrm{~N} 26$ (male flower), $70.8 \%$ in 'Hicaz' $\times 33$ N 26 (hermaphrodite flower), $46.0 \%$ in $33 \mathrm{~N}$ 26 open pollination, $50.3 \%$ in $33 \mathrm{~N} 26 \times 33 \mathrm{~N} 26$ (male flower), $46.4 \%$ in $33 \mathrm{~N} 26 \times 33 \mathrm{~N} 26$ (hermaphrodite flower), $68.5 \%$ in $33 \mathrm{~N} 26 \times$ 'Hicaz' (male flower), $61.8 \%$ in $33 \mathrm{~N} 26 \times$ 'Hicaz' (hermaphrodite flower) (Derin and Eti, 2001). In another study with seven pomegranate cultivars at ETAE, the fruit set ratios were obtained as $82.8 \%$ in selfing and $94.2 \%$ in open pollination (Küçük 2003). In this current study, the fruit set ratios of the progeny were between those of their parents. In most cases, selfpollination gives lower fruit set ratio than open pollination. The reason for that could be self-, cross-, or groupincompatibility among cultivars.

\section{Anthernumbers}

The number of anthers was the same (337) in both hermaphrodite and male pomegranate flowers (Table 3 ). The number of anthers per hermaphrodite and male flowers was changed between 284 in male flowers of 'Efenar $35^{\prime}$ and 402 in hermaphrodite flowers in 'Tezeren 35 ' cultivars, respectively. 
Table 1. Phenological stages of hermaphrodite and male flowers in pomegranate cultivars in 2015

\begin{tabular}{|c|c|c|c|c|c|c|}
\hline \multirow{2}{*}{ Cultivar } & \multicolumn{2}{|c|}{ Beginning of flowering } & \multicolumn{2}{|c|}{ Full flowering } & \multicolumn{2}{|c|}{ End of flowering } \\
\hline & Hermaphrodite & Male & Hermaphrodite & Male & Hermaphrodite & Male \\
\hline 'Dr. Ercan 35' & 11 May & 05 May & 30 May & 25 May & 23 June & 15 May \\
\hline 'Efenar 35’ & 08 May & 27 May & 25 May & 30 May & 07 June & 15 June \\
\hline 'Kamilbey 35' & 05 May & 12 May & 17 May & 25 May & 09 June & 16 June \\
\hline 'Tezeren 35' & 14 May & 14 May & 02 June & 19 May & 23 June & 15 June \\
\hline
\end{tabular}

Table 2. Fruit set in different cross experiments in pomegranate cultivars (\%)

\begin{tabular}{|c|c|c|c|c|c|c|}
\hline$\overline{C u l t i v a r}$ & Open* & Dr. Ercan 35 & Efenar 35 & Kamilbey 35 & Tezeren 35 & Average \\
\hline 'Dr. Ercan 35' & $85.0 \mathrm{a}$ & $60.3 \mathrm{a}-\mathrm{d}$ & $13.9 \mathrm{fg}$ & $20.4 \mathrm{fg}$ & $38.3 \mathrm{c}-\mathrm{f}$ & $43.6^{\mathrm{ns}}$ \\
\hline 'Efenar 35' & $82.6 \mathrm{a}$ & $9.0 \mathrm{~g}$ & $62.4 \mathrm{a}-\mathrm{c}$ & $13.7 \mathrm{fg}$ & $13.9 \mathrm{fg}$ & 36.3 \\
\hline 'Kamilbey 35' & $75.0 \mathrm{ab}$ & $49.7 \mathrm{~b}-\mathrm{e}$ & $32.8 \mathrm{e}-\mathrm{g}$ & $50.0 \mathrm{~b}-\mathrm{e}$ & $16.0 \mathrm{fg}$ & 44.7 \\
\hline 'Tezeren 35’ & $60.1 \mathrm{a}-\mathrm{d}$ & $38.6 c-f$ & $35.1 \mathrm{~d}-\mathrm{g}$ & $29.8 \mathrm{e}-\mathrm{g}$ & $25.2 \mathrm{e}-\mathrm{g}$ & 37.8 \\
\hline Average & $75.7 \mathrm{a}$ & $39.4 \mathrm{~b}$ & $36.1 \mathrm{bc}$ & $28.5 \mathrm{bc}$ & $23.3 \mathrm{c}$ & \\
\hline $\operatorname{LSD}_{(0.05)}($ Cultivar $)$ & ns & & & & & \\
\hline $\operatorname{LSD}_{(0.05)}($ Pollinator $)$ & 13.8 & & & & & \\
\hline
\end{tabular}

Table 3. Number of anthers per flower in pomegranate cultivars

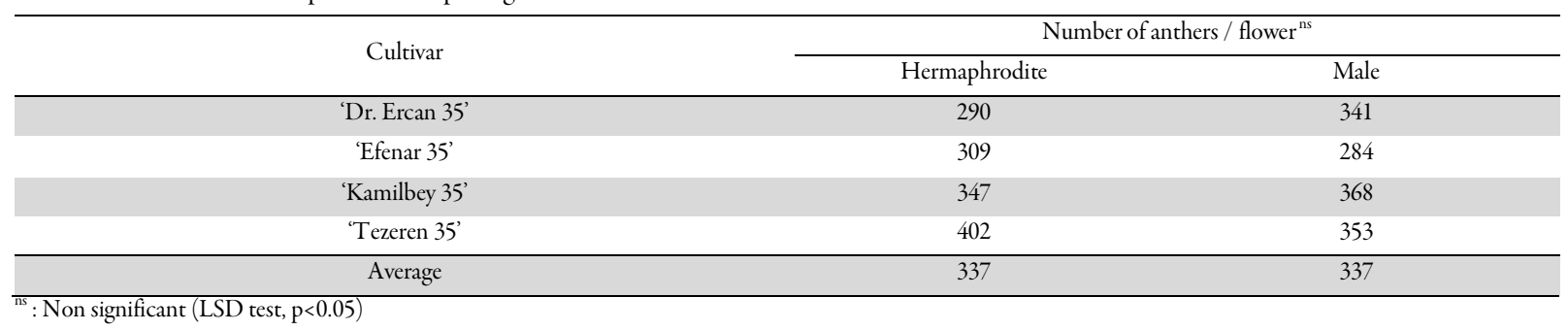

\section{Pollen numbers}

The number of pollens per anther and per flower was changed between 1,459 and 583,333 in hermaphrodite flowers in 'Tezeren 35', and 8,550 and 3,083,333 in male flowers in 'Kamilbey 35' cultivars in the beginning of flowering, respectively (Table 4). The highest number of pollen grains was obtained in full flowering. In general, male flowers $(4,841)$ had more pollen than hermaphrodite flowers $(3,511)$.

The number of pollen grains per anther and flower was 1,061 (hermaphrodite in 'Ekşilik' cultivar) and 1,008 (male in 'Aşınar' cultivar) and 215,625 (hermaphrodite) and 198,750 (male), respectively, (Gözlekçi and Kaynak, 2000). The highest pollen grain per anther in male flowers was 3,055 and 2,701 in 'Hicaz' and $33 \mathrm{~N} 36$ pomegranate cultivars, respectively (Derin and Eti, 2001). The number of pollen grains was 472,188 per hermaphrodite and 992,875 per male flowers (Küçük, 2003). Şahin (2004) determined the number of pollen grains per anther as 485 in hermaphrodite and 1,353 in male flowers in 'Hicaz' pomegranate cultivar. The highest number of pollen grains per anther and flower as 300 and 330, and 1,036,380 and $2,143,700$, in hermaphrodite and male flowers, respectively (Üstüntaş et al., 2019).

\section{Pollen viability}

The ratio of pollen viability was changed from $39.4 \%$ in hermaphrodite flowers at the end of flowering in 'Tezeren $35^{\prime}$ to $84.7 \%$ in hermaphrodite flowers at the beginning of flowering in 'Efenar 35' (Table 5). The differences were significant in cultivar $\times$ time $\times$ type, cultivar $\times$ time, time $\times$ type, cultivar, and time at $p<0.05$. According to the cultivars, the highest pollen viability was recorded in 'Kamilbey 35' (67.2\%) and 'Efenar 35' (65.5\%). According to the flowering time, the highest of that was observed in the beginning of flowering (74.5\%) followed by full flowering $(63.2 \%)$ and end of flowering (51.4\%). According to cultivar $\times$ time interaction, the highest pollen viability was observed in 'Dr. Ercan 35' in the beginning of flowering $(81.7 \%)$. According to the type $\times$ time interaction, the highest pollen viability was observed in the hermaphrodite flowers in the beginning of flowering (79.0\%). According to cultivar $\times$ time $\times$ type interaction, the highest pollen viability was observed in 'Efenar $35^{\prime} \times$ beginning of flowering $\times$ hermaphrodite flower combination $(84.7 \%)$.

The pollen viability ratios in TTC were found as $70.3 \%$ and $68.6 \%$ in hermaphrodite flowers, and $75.2 \%$ and $72.4 \%$ in male flowers in 'Hicaz' and $33 \mathrm{~N} 26$ cultivars, respectively, (Derin and Eti, 2001). In India, the highest pollen viability was observed as $65.2-62.2 \%$ in $1 \%$ TTC test (Prakash et al., 2010). The highest number of pollen viability and germination was $75.2 \%$ (TTC) and $61.5 \%$ (1\% agar $+10 \%$ sucrose), respectively, in male flowers in 'Hicaz' which is a dominated pomegranate cultivar in Turkey (Küçük, 2003).The highest pollen viability in TTC test was recorded in $95.0 \%$ in hermaphrodite flowers in the end of flowering and $92.4 \%$ in male flowers in the beginning of flowering (Üstüntaş et al., 2019). 


\section{Pollen germination}

The ratio of pollen germination was changed from $14.9 \%$ in the hermaphrodite flowers at the end of flowering in 'Kamilbey 35 ' to $71.2 \%$ in the hermaphrodite flowers at the beginning of flowering in 'Kamilbey 35' (Table 6). The differences were significant in cultivar $\times$ time $\times$ type, cultivar $\times$ time, cultivar $\times$ type, time $\times$ type, cultivar, time, and type at $p<0.05$. According to the cultivars, the highest pollen germination was recorded in 'Dr. Ercan 35' (44.9\%) and 'Efenar 35' (42.9\%). According to the flowering times, the highest of that was observed in the beginning of flowering $(53.2 \%)$ followed by full flowering $(40.9 \%)$ and end of flowering (28.6\%). According to the flower types, the pollen germination ratios were observed in hermaphrodite flowers (42.7\%) followed by male flowers (39.1\%). According to cultivar $\times$ time interaction, the highest pollen germination was observed in 'Efenar 35' in the beginning of flowering (59.9\%) and 'Dr. Ercan 35' in the beginning of flowering (59.8\%). According to cultivar $\times$ type interaction, the highest pollen germination was observed in both types of flowers in 'Dr. Ercan 35', 'Efenar 35', and hermaphrodite flowers in 'Tezeren 35'. According to the time $\times$ type interaction, the highest pollen germination was observed in the hermaphrodite flowers in the beginning of flowering $(65.4 \%)$. According to cultivar $\times$ time $\times$ type interaction, the highest pollen germination was observed in 'Kamilbey $35^{\prime} \times$ beginning of flowering $\times$ hermaphrodite flower combination $(71.2 \%)$. The best pollen germiantion ratio $(22.8 \%)$ in male flowers of pomegranate clone ME15, a Mollar type, was obtained from $1.5 \%$ agar $+10 \%$ sucrose (Melgarejo et al., 2000). Derin and Eti (2001) recommended $12.5 \%$ sucrose $+0.5 \%$ agar for the best pollen germination medium. Engin and Hepaksoy (2007) found that $15 \%$ and $20 \%$ sucrose gave better pollen germination ratios than $10 \%$ sucrose.

Table 4. Pollen numbers per anther and per flower in pomegranate cultivars

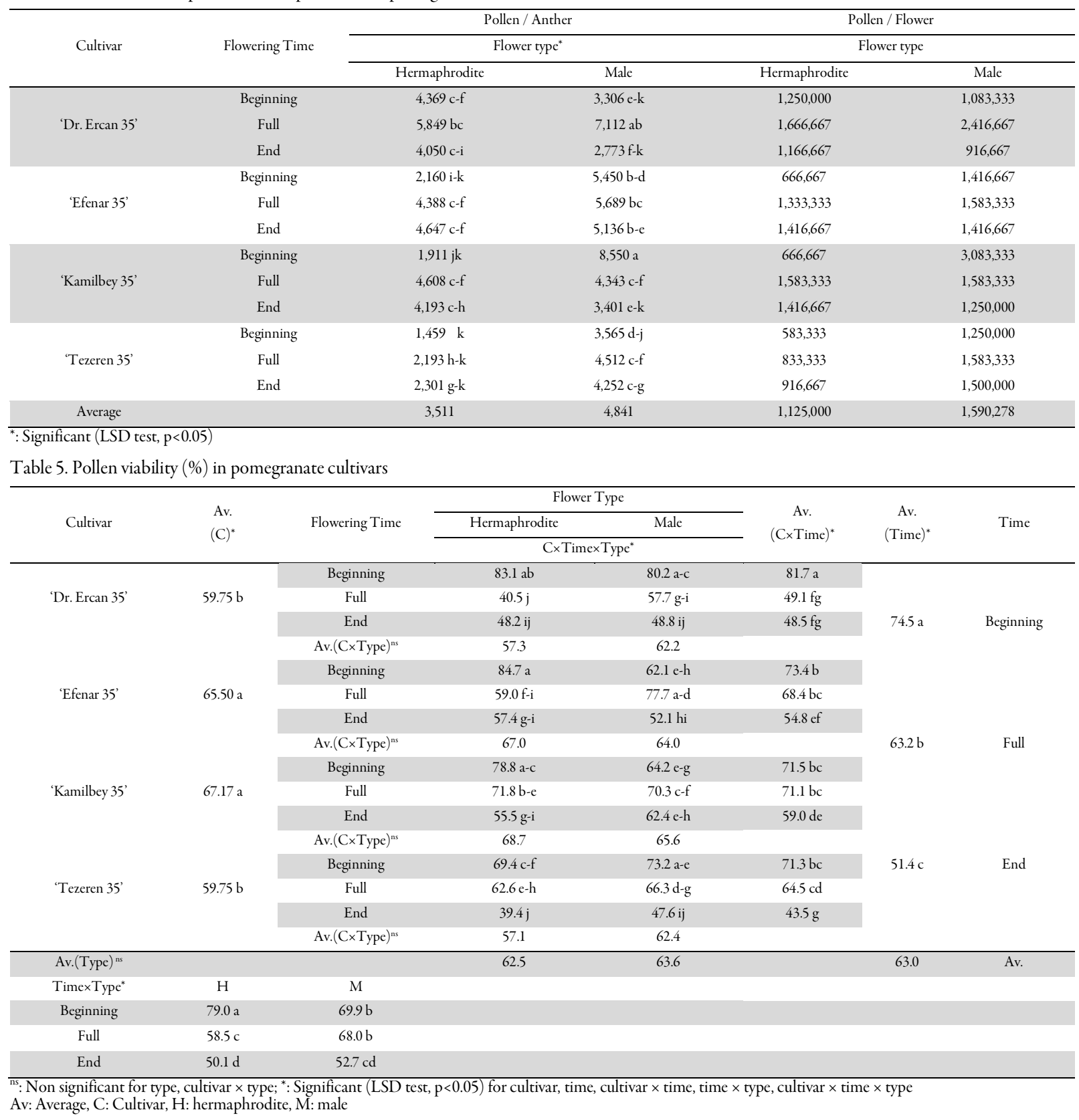


1262

Table 6. Pollen germination (\%) in pomegranate cultivars

\begin{tabular}{|c|c|c|c|c|c|c|c|}
\hline \multirow{3}{*}{ Cultivar } & \multirow{3}{*}{$\begin{array}{l}\text { Av. } \\
(C)^{*}\end{array}$} & \multirow{3}{*}{ Flowering Time } & \multicolumn{2}{|c|}{ Flower Type } & \multirow{3}{*}{$\begin{array}{c}\text { Av. } \\
(\mathrm{C} \times \text { Time })^{*}\end{array}$} & \multirow{3}{*}{ 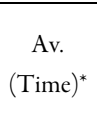 } & \multirow{3}{*}{ Time } \\
\hline & & & Hermaphrodite & Male & & & \\
\hline & & & \multicolumn{2}{|c|}{ C $\times$ Time $\times$ Type ${ }^{*}$} & & & \\
\hline \multirow{3}{*}{ 'Dr. Ercan 35' } & \multirow{3}{*}{$44.9 \mathrm{a}$} & Beginning & $62.7 \mathrm{ab}$ & $56.9 \mathrm{bc}$ & $59.8 \mathrm{a}$ & \multirow{6}{*}{$53.2 \mathrm{a}$} & \multirow{6}{*}{ Beginning } \\
\hline & & Full & $29.4 \mathrm{gh}$ & $51.6 \mathrm{~cd}$ & $40.5 \mathrm{bc}$ & & \\
\hline & & End & $35.8 \mathrm{e}-\mathrm{g}$ & $33.2 \mathrm{fg}$ & $34.5 \mathrm{~cd}$ & & \\
\hline \multirow{5}{*}{ 'Efenar 35' } & \multirow{5}{*}{$42.9 \mathrm{ab}$} & Av. $(\text { C×Type })^{*}$ & $42.6 \mathrm{AB}$ & $47.2 \mathrm{~A}$ & & & \\
\hline & & Beginning & $63.4 \mathrm{ab}$ & $56.4 \mathrm{bc}$ & $59.9 \mathrm{a}$ & & \\
\hline & & Full & $29.0 \mathrm{gh}$ & $44.7 \mathrm{de}$ & $36.9 \mathrm{~cd}$ & & \\
\hline & & End & $36.7 \mathrm{e}-\mathrm{g}$ & $27.0 \mathrm{gh}$ & $31.9 \mathrm{~d}$ & \multirow{3}{*}{$40.9 \mathrm{~b}$} & \multirow{3}{*}{ Full } \\
\hline & & Av. $(\mathrm{C} \times \text { Type })^{*}$ & $43.0 \mathrm{AB}$ & $42.7 \mathrm{AB}$ & & & \\
\hline \multirow{3}{*}{ 'Kamilbey 35' } & \multirow{3}{*}{$36.4 \mathrm{c}$} & Beginning & $71.2 \mathrm{a}$ & $21.9 \mathrm{hi}$ & $46.6 \mathrm{~b}$ & & \\
\hline & & Full & $34.2 \mathrm{fg}$ & $43.0 \mathrm{~d}-\mathrm{f}$ & $38.6 \mathrm{~cd}$ & \multirow{7}{*}{$28.6 \mathrm{c}$} & \multirow{7}{*}{ End } \\
\hline & & End & $14.9 \mathrm{i}$ & $33.2 \mathrm{fg}$ & $24.1 \mathrm{e}$ & & \\
\hline \multirow{5}{*}{ 'Tezeren $35^{\prime}$} & \multirow{5}{*}{$39.4 \mathrm{bc}$} & Av. $(\mathrm{C} \times \text { Type })^{*}$ & $40.1 \mathrm{~B}$ & $32.7 \mathrm{C}$ & & & \\
\hline & & Beginning & $64.4 \mathrm{ab}$ & $28.9 \mathrm{gh}$ & $46.7 b$ & & \\
\hline & & Full & $43.4 \mathrm{~d}-\mathrm{f}$ & $52.3 \mathrm{~cd}$ & $47.9 \mathrm{~b}$ & & \\
\hline & & End & $27.3 \mathrm{gh}$ & $20.3 \mathrm{hi}$ & $23.8 \mathrm{e}$ & & \\
\hline & & Av. $(\text { C } \times \text { Type })^{*}$ & $45.0 \mathrm{AB}$ & $33.8 \mathrm{C}$ & & & \\
\hline Av. $(\text { Type })^{*}$ & & & $42.7 \mathrm{a}$ & $39.1 \mathrm{~b}$ & & 40.9 & Av. \\
\hline TimexType* & $\mathrm{H}$ & M & & & & & \\
\hline Beginning & $65.4 \mathrm{a}$ & $41.0 \mathrm{c}$ & & & & & \\
\hline Full & $34.0 \mathrm{~d}$ & $47.9 \mathrm{~b}$ & & & & & \\
\hline End & $28.7 \mathrm{e}$ & $28.4 \mathrm{e}$ & & & & & \\
\hline
\end{tabular}

In India, the highest pollen germination ratio in the beginning and full flowering periods were $45.8 \%$ and $42.3 \%$, respectively, in 15\% sucrose (Prakash et al., 2010).

The highest percentage of germination (70\%) was obtained for 'Alktorshtabrizi' cultivar in 1.5\% agar $+10 \%$ sucrose $+50 \mathrm{mg} \mathrm{L}^{-1} \mathrm{NAA}$ and IBA $+100 \mathrm{mg} \mathrm{L}^{-1}$ boric acid (Imani and Nazarian, 2013). The highest ratio of pollen germination was observed as $29.1 \%$ and $19.5 \%$ in hermaphrodite and male flowers, respectively, in the beginning of flowering in $1 \%$ agar $+20 \%$ sucrose $+25 \mathrm{ppm}$ boric acid (Üstüntaş et al., 2019).

\section{Conclusions}

The number of anthers per flower was not different among cultivars and flower types. The highest number of pollen grains per flower was in male flowers in the beginning of flowering in 'Kamilbey 35'. The highest pollen viability was in hermaphrodite flowers at the beginning of flowering in 'Efenar 35'. The highest pollen germination in hermaphrodite flowers at the beginning of flowering in 'Kamilbey 35'. The highest fruit set in self-pollination was in 'Efenar 35' and 'Dr. Ercan'. The highest fruit set was in 'Kamilbey 35' × 'Dr. Ercan 35' cross combination. These new pomegranate cultivars, 'Dr. Ercan 35', 'Efenar 35', 'Kamilbey 35', and 'Tezeren 35', are recommended in the Mediterranean climate to be used both fruit production and as pollinators to the international and national standard pomegranate cultivars.

\section{Acknowledgements}

This work was supported by Aydın Adnan Menderes University Scientific Research Project (ADÜ BAP), grant number ZRF-16023 to D. A. for his Master of Science thesis.

\section{Conflict of Interest}

The authors declare that there are no conflicts of interest related to this article.

\section{References}

Anonymous (2017). TÜİK-Turkish statistical institute. Retrieved 2017 July 01 from http://www.tuik.gov.tr.

Dalka Y (2010). Hicrannar ve Canernar (Punica granatum L.) çeşitlerinde çiçeklenme döneminin meyve tutumu, pomolojik özellikler ve kalite üzerine etkisi [Effects of blooming periods on fruiting ratio, some pomological properties and quality characteristics of Canernar and Hicrannar pomegranate (Punica granatum L.) varieties in Antalya District]. MSc Thesis, Gaziosmanpaşa Üniversitesi, Tokat, Turkey pp 25.

Derin K,EtiS (2001).Determination of pollen quality, quantity and effect of cross-pollination on the fruit set and quality in the pomegranate. Turkish Journal of Agriculture and Forestry 25(3):169-173. 
El-Kassas SE, El-Sese AM, El-Salhy AM, Abdalla AA (1988). Bearing habits in some pomegranate cultivars. Assiut Journal of Agricultural Science 29:147-162.

Engin H, Hepaksoy S (2003). Bazı nar çeşitlerinin çiçek tozu çimlenme güçlerinin belirlenmesi [Determination of pollen germination of some pomegranate cultivars]. Ege Üniversitesi Ziraat Fakültesi Dergisi 40:916.

EtiS (1990). Eine praktische Methode zur Festsellung der Pollenproduktion [A practical method for determination of pollen amount]. Çukurova ÜniversitesiZiraat Fakültesi Dergisi 5:49-58.

Eti S (1991). Die Beurteilung der Lebens- und Keimfähigkeiten der Pollenkörner einiger Ostarten und- sorten mit Hilfe von in vitro-Tests [Determination of pollen viability and germination ability using different in vitro tests in some fruit species and varieties]. Çukurova ÜniversitesiZiraat Fakültesi Dergisi 6:69-81.

Gözlekçi Ş (2014). Past, present, and future of pomegranate [Narın geçmişi, bugünüve geleceği]. Türktob 3:20-23.

Gözlekçi Ş, Kaynak L (2000). Investigations on pollen production and quality in some standard pomegranate (Punica granatum L.) cultivars. CIHEAM Options Méditerranéennes: Série A. Séminaires Méditerranéens 42:71-77.

Gözlekçi Ş, Ercişli S, Okturen F, Sonmez S (2011). Physico-chemical characteristics at three development stages in pomegranate $\mathrm{cv}$. 'Hicaznar'. Notulae Botanicae Horti Agrobotanici Cluj-Napoca 39(1):241-245.

Günver-Dalkılıç G, Dayı-Doğru Ö (2011). Determination of pollen grain viability and germination levels for pistachio and terebinth in Aydın/Turkey ecology. Pakistan Journal of Botany 43(2):841-848.

Holland D, Hatib K, Bar-Ya'akov I (2009). Pomegranate: botany, horticulture, breeding. Horticultural Reviews 35(2):127-191.

Imani A, Nazarian M (2013). Effects of boron and growth regulators on germination of Punica granatum pollen grains. Advanced Crop Science $3(4): 268-272$.

Jalikop SH (2010). Pomegranate breeding, Fruit, Vegetable and Cereal Science and Biotechnology 4:26-34.

Küçük E (2003). Determination of self-fruitfulness of some pomegranate (Punica granatum L.) cultivars [Bazı nar (Punica granatum L.) çeşitlerinin kendine verimlilik durumlarının saptanmasi] MSc Thesis. Ege Üniversitesi, İzmir, Turkey, pp 38.
Mars M(1998). Pomegranate plant material: genetic resources and breeding, a rewiew. Options Mediterraneennes A 42:55-62.

Melgarejo P, Martínez JJ, Hernández F (2000). A study of different culture media for pomegranate (Punica granatum L.) pollen. CIHEAM Options Méditerranéennes: Série A. Séminaires Méditerranéens 42:6369.

Melgarejo P, Martínez JJ, Hernández F, Legua P, Melgarejo-Sánchez P, Martínez Font R (2012). The pomegranate tree in the world: its problems and uses. In: Options méditerranéennes. Séries A: Mediterranean Seminars. CIHEAM-IAMZ, Zaragoza, Spain; Universidad Miguel Hernández, Elche,Spain.

Onur C (1988). Pomegranate [Nar].Derim 5:147-191.

Prakash A, Chauhan S, Rana A, Chaudhary V (2010). Study of in vitro pollen germination and pollen viability in Punica granatum L. (Punicaceae). Research Journal of Agricultural Sciences 1(3):224226.

Şahin A (2004). Biological studies on pomegranate (Punica granatum cv. Hicaznar) which is grown in Antalya [Antalya bölgesinde yetisstirilen Hicaznar (Punica granatum cv. Hicaznar) üzerinde biyolojik araştırmalar] MSc Thesis, Akdeniz Üniversitesi, Antalya, Turkeypp 38.

Stover E, Mercure EW (2007). The pomegranate: a new look at the fruit of paradise. HortScience 42(5):1088-1092.

Tibet H, Baktır İ(1991). Flowering in pomegranates [Narlarda çiçeklenme]. Derim 8:166-173.

Üstüntaş T, Dalkullç Z, Günver Dalkuliç G (2019). Effect of stigma exudate on pollen germination in pomegranate. Acta Horticulturae 1254:109114.

Wetzstein HY, RavidN, Wilkins R, Martinelli AP (2011).A morphological and histological characterization of bisexual and male flower types in pomegranate. Journal of the American Society for Horticultural Science 136(2):83-92.

Yazıı K, Şahin A (2016). Characterization of pomegranate (Punica granatum L.) hybrids and their potential use in further breeding. Turkish Journal of Agriculture and Forestry 40(6):813-824.

Yilmaz C (2007). Pomegranate [Nar]. Hasad YayıncllkLtd. Şti, İstanbul pp 176. 